Prof. D.G. Firth

Trinity College, Bristol

/ Research fellow:

University of the Free

State, South Africa.

E-mail: d.firth@

trinitycollegebristol.

ac.uk

DOI: http://dx.doi.

org/10.18820/23099089/

actat.v38i2.5

ISSN 1015-8758 (Print)

ISSN 2309-9089 (Online)

Acta Theologica 2018

38(2):70-86
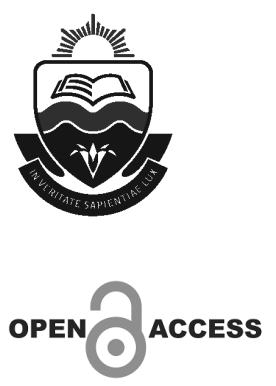

\section{JOSHUA 24 AND THE WELCOME OF FOREIGNERS}

\section{ABSTRACT}

Although the book of Joshua is often read as being hostile to non-Israelites, this paper argues that its concern is not with ethnicity but rather with the nature of someone's relationship to Yahweh. Understood against the wider narrative arc of the book, Joshua 24 thus becomes the point where this is explored in full. This then establishes a pattern that runs through the Former Prophets which consistently demonstrate the possibilities for foreigners within Israel. The means by which this is presented suggest that Joshua in particular is arguing against a dominant social model which is opposed to foreigners. From this, it can be seen that Joshua is establishing an ethical paradigm which is welcoming to those who commit to Yahweh.

\section{INTRODUCTION}

In Joshua 24:14 - 15, Joshua stands before the assembled people at Shechem and makes his oft-cited challenge to those gathered to "choose this day whom you will serve" before going on to insist that he and his family will serve (עבד) Yahweh. Within the narrative structure of the book of Joshua, the appeal is a striking one. This is not only because of the difficulties that interpreters of the book have typically noted with chapter 24 as a whole (see Butler 2014: 297-316, or Earl 2010: 189-191, for a helpful summary), but more specifically because of the issues that Joshua raises within his appeal. Put simply, Joshua demands that his audience put away the gods of their ancestors and serve Yahweh alone. The remarkable thing to note here is that although this removal of other gods is the central point in 
Joshua's appeal, it raises an issue that has not featured directly at any earlier point within the book.

We can note the importance of this by looking at the structure of the final form of the book and noting how this issue emerges. In each of chapters 22, 23 and 24 we have a farewell speech from Joshua, each one roughly twice as long as its predecessor $(22: 1-8,23: 1-16,24: 1-28)$, and it is only in these chapters that the existence of other gods is noted. The first reference occurs in the narrative of the altar on the Jordan which follows on from the initial speech when the cis-Jordanian tribes are sent back to their territory, though here the possibility of other gods existing is somewhat oblique as the cis-Jordanians declare "Yahweh is God of gods! Yahweh is God of gods!" (Josh. 22:22). The superlative here allows that Yahweh be understood as the ultimate deity, but beyond this there is no interest in other gods. In the second farewell there are two further references to other gods, in Joshua 23:7 and 16. But both of these references are oriented to a future problem that Israel might encounter and which Joshua seeks to prevent, although acknowledging that the problem arises from the position in which Israel found itself at that point. That is, because Israel was dwelling among nations which remained with them then it would be possible for them to forget the requirements of Torah and so serve those gods (Josh. 23:6-8). If Israel made that choice, then they would bring Yahweh's wrath upon themselves. The crucial point to notice here is that although the farewell speeches and their attached narratives have recognised the existence of other gods (however understood), at no point has the worship of other gods been anything more than a possibility to avoid.

Yet when we come to the third of the farewell speeches, the issue of other gods comes to central prominence. They are mentioned seven times within the chapter (Josh. 24:2, 14, 15 (x2), 16, 20, 23), six times by Joshua himself, and once by the people in response (Josh. 24:16). Reference to and worship (עבד) are part of a web of repeating terms which hold this chapter together (Sperling 1987:121-122). Apart from 24:2, which refers to the gods worshipped by the ancestors in the past when they lived beyond the Euphrates (though we will need to return to this), all the other references assume that there is at least a significant portion of the crowd present who were currently worshippers of deities other than Yahweh. These people could be understood as syncretistic worshippers or simply as those who gave their devotion to deities other than Yahweh. We are not given the information to decide which unless we are to understand the people's response in 24:16 as indicating that they saw themselves as Yahweh worshippers who also worshipped other deities. In any case, the text 
assumes the presence at Shechem of a significant body of people for whom the worship of other deities was a present reality.

Unsurprisingly, this has been an important element in historical-critical treatments of this chapter, but for our purposes it is more important to note the ways in which this emerges within the finished book. Because, although references to foreign gods have not been frequent earlier in the book, the issue of faithfulness to Yahweh (note that the appeal is to serve Yahweh with wholehearted faithfulness, בתמים ובאמת) is tied to other key themes within the book. It is the confluence of the themes of such faithfulness and the gradual emergence of reference to other gods in the farewell speeches which helps this chapter to fit within the overall narrative arc of the finished text. That is, whatever date is assigned to this chapter relative to the finished redaction of the book as a whole, we can trace a series of themes which lead to this appeal. When we trace these themes in terms of the presence of foreigners within the book of Joshua it is possible to see that the inclusion of foreigners within Israel is at least one trigger for Joshua's appeal, because it is their presence which highlights the threat posed to Israel by other gods in the terms outlined in the previous chapter. Indeed, a key element within the book has been to redefine the concept of Israel so that it can be understood as a mixed group for whom biological descent is only a lesser marker of membership whereas commitment to Yahweh alone is the dominant marker. It is the transformation of Israel's ethnic identity within the book which enables this appeal to make narrative, and hence ethical, sense. Israel is to be defined by a radical theological commitment, and that theological commitment always transcends any ethnic association. So, although Joshua is often read as a text which is solely about the destruction of the Canaanite peoples (e.g. Cowles, 2003), a closer reading of the book will show that it actually devotes more time to including foreigners than devoting them to destruction, and that the key issue is wholeheartedly faithful worship of Yahweh. It is this which is vital to understanding the book's ethical stance relative to foreigners, a stance which it is argued here is not the bloodthirsty xenophobia that it is often assumed to be (e.g. Coote 1998: 578, Dawkins 2006: 280, Mann 2011: 22).

\section{FOREIGNERS AND THE TAKING OF THE LAND IN JOSHUA 1-12}

For many contemporary readers, Joshua is perhaps the most difficult text in the Old Testament because of its attitude to foreigners, and especially to the Canaanites. Somewhat against the flow of the main lines of interpreting the book, however, Markus Zehnder has shown that there is a 
much more positive interpretation of foreigners offered, one in which the Canaanite population had the opportunity to turn to Yahweh and thus not face destruction (Zehnder 2005:483-487; 2013; c.f. Firth 2017a).Taking Zehnder's insights further, the aim of this section of this paper is to show how the positive possibilities for Canaanites and other foreigners are presented in these chapters whilst also acknowledging that the possibility of their destruction (שמד) or being placed under the ban (חרם) remain as very real possibilities.

To appreciate the importance of this point, it is vital that we pause to note a key element of the narrative form of the book, and a key shift which takes place after 5:12 (agreeing with the analysis of Koorevaar 1990:117, though for different reasons). Up to this point, the narrative has followed a pattern of external focalisation, a mode of narration in which the narrator provides a description of events but without providing direct guidance on the significance of these events and how they are to be interpreted. In Joshua's encounter with the commander of Yahweh's army (5:13-15), the narrative is briefly internally focalised (i.e. we see Joshua's perspective) but thereafter, although the narrator will occasionally hold back information for rhetorical effect, the pattern is generally to present a zero focalised narrative. That is, one where the narrator not only recounts events but also provides the reader with guidance on how they are to interpret them (Genette 1980:187). Without this guidance, readers may piece together clues, but they do not have direct guidance from the narrator, and by withholding direct interpretative information a skilled narrator may create one set of expectations only to reveal them to be flawed and so to be rejected, thus disorienting readers (see Firth 2017b).

Indeed, in these chapters of Joshua this is the strategy that is employed. In Joshua 1, the narrator establishes a series of links with Deuteronomy, all of which are related to the anticipated destruction of the Canaanites (Firth 2017b). However, where a narrator creates an intertextual reference, but does not provide a clear means of understanding it, there is always scope for misreading, or perhaps being misled because the hints in the text are only partial. Further, as Krause (2014: 56-58) has argued, such references can be an appeal, an allusion or an explanation. In the case of the first and third of his categories, the narrator needs to provide the reader with sufficient information to understand the reference, but this is not the case where we have an allusion, since the allusion is by its very nature open. All of the references to Deuteronomy in this chapter are allusions, which readers then interpret by closing the gaps, but the narrator does not do this. So, Hawk (2000: 35) can argue that this chapter creates the expectation of the destruction of the Canaanites, meaning that 
the agreement reached by the spies with Rahab in Joshua 2 represents a significant mistake by Israel. Although, in taking this position he is well aware that he is standing against the dominant reading of the Christian tradition which has interpreted Rahab positively. However, although the links he notes with Deuteronomy are all valid, he has closed gaps which the narrative leaves open because of the narrator's desire to destabilise readers. ${ }^{1}$ It is the openness of the allusions that is vital to their function.

Likewise, this openness means that although there is a strong tradition of reading Rahab as a positive character in Joshua 2, the absence of any narrative comment means that by the end of that chapter we do not know if she is an "acceptable exception" (so Winther-Nielsen, 1995: 105-162) or if Israel has made the sort of fundamental mistake proposed by Hawk. What we can say is that Rahab is able to make the sort of confession of faith that would do any Deuteronomist proud and demonstrates this by her actions in ensuring the release of the two scouts sent by Joshua. But we do not know if she is a shrewd woman who has prevailed over the spies (Hawk 1991:71-72), a clever trickster who does what is necessary to survive (García-Alfonso 2010: 39-62) or a negotiated exception to the destruction of the Canaanites (Winther-Nielsen 1995: 162). Perhaps, though, things are left deliberately open at this point, because the narrator is doing something more daring. All Canaanites could easily have been "othered", treated as a people to be rejected and so not capable of being trusted because they can so easily lead Israel astray, something Joshua himself notes as being possible in 23:7, 16. But instead, the narrative in Joshua 2 chooses to present readers with a Canaanite who, against all expectations, seems to show a greater awareness of Israel's faith than do the scouts. She stands against Israel's previous experience of foreign women (Numbers 25:1 - 5, c.f. Krause 2015), so that rather than demonising all Canaanites, the presentation of her serves to open up questions about the place of foreigners, especially Canaanites.

For the overall narrative, though, it is important to note that we do not have a clear interpretation of her position until the capture of Jericho in chapter $6 .^{2}$ That resolution begins with the shift in narrative style at 6:1-2, where in spite of Jericho being shut up, Yahweh can promise in advance of the siege narrative itself that the city was already given over to Israel.

1 One might suggest that the narrator is setting out to deconstruct a view which was dominant at the time and so which needed careful rejection - taking it on directly might lead to immediate rejection, whereas the more oblique approach noted here allows for the view to be heard even by those who might otherwise wish to reject it.

2 The capture of Jericho begins to resolve a number of issues laid out in the first five chapters, a resolution that continues to run through to Joshua 11:23. 
Admittedly, even the references to Rahab in Joshua 6 could be interpreted as being unresolved since the directive to bring her and her family out are presented as directives from Joshua rather than Yahweh (6:17), whilst the fact that she and her family continued to dwell within Israel is simply a narrative aside (6:25). But since the narrator comments directly that they continued to dwell within Israel because she hid the messengers sent by Joshua (6:25), and that it was because Yahweh was with Joshua that his renown spread through the land, it is much more likely that we are to understand Joshua's actions as a working out of the commands given to him by Yahweh. Retrospectively, then, Yahweh (through the narrator) vindicates the agreement with Rahab, leading in turn to her positive representation in the New Testament (Matt. 1:5, Heb. 11:31, Jas 2:25). Wholehearted faithfulness to Yahweh has indeed been demonstrated.

We can pass over the other references to foreigners being included in Israel within this section of the book more briefly, but they are still worth noting, especially when we also note that the story of Achan in Joshua 7 is in essence a mirror to the story of Rahab, where an Israelite who places his own wishes above those of Yahweh is effectively treated as a Canaanite (c.f. Billings, 2013:25-52). This is a narrative where Canaanites become Israelites and Israelites become Canaanites, subverting expectations, with the key issue being whether or not there is wholehearted faithfulness to Yahweh. This in turn prepares readers for the somewhat surprising presence of the גר in Joshua 8:30 - 35. Although the term גר could at times refer to a displaced Israelite rather than a foreigner (however this might have been understood in the Old Testament), that the גר is expressly contrasted with the native born makes clear that this text presumes that foreigners are present at the ceremony described here. ${ }^{3}$ But since the only foreigners mentioned in the narrative to this point are Canaanites, then we have to assume that they are (at least) a significant portion of this group, probably deriving principally from the Rahab group. By following Yahweh's commands through Moses for a ceremony at Mt Ebal, these foreigners demonstrate the wholehearted commitment Joshua expects. This is complicated further by the presence of the Gibeonites within Israel since they enter into a covenant with Israel by means of deception, though finally ending with a position where they work in an admittedly menial role in the

3 Where this ceremony fits into the chronology of Joshua cannot be discussed here, but the more important point is that it now functions as a comment on the narrative to this point, so that the most obvious foreigners included would be Canaanites. This is complicated by the variations in the textual tradition

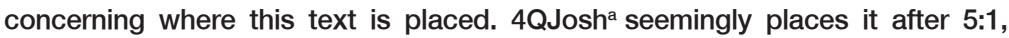
whereas $L X X$ has it after 9:2. Although I would defend the current location in MT, it does not affect the position argued here on the significance of this passage. 
sanctuary (Josh. 9:3-27). But they too end up offering a possible future for Canaanites who are prepared to work for Israel rather than resist them (c.f. Ford 2015).

By the end of Joshua 12, Israel has successfully taken significant territory in both the south and the north, and in both chapters 10 and 11 we see Israel destroying Canaanite groups who attack them. However, the fact that 10:20 can simultaneously affirm that one group was wiped out and also that a remnant fled makes clear that much of the language is hyperbolic. Indeed, cities which are here said to have been destroyed reappear in the land allocation as needing to be taken (e.g. Hebron, compare 10:36-37 and 14:14). Rahab, a Canaanite, actually emerges as the paradigm figure for these chapters, the one who truly understands what Yahweh is doing and acts upon this, and so encourages Israel through both her words and her actions on behalf of Israel. A Canaanite who displays wholehearted faithfulness becomes a part of the community. Ethnicity does not matter in this context. Commitment to Yahweh does, though the more limited example of the Gibeonites suggests that this commitment might not yet be absolute. But lest there be any confusion on this point, the narrator explicitly comments that Joshua had left nothing undone of all that Yahweh had commanded through Moses (11:15), whilst the presence of the Gibeonites is also due to Yahweh's initiative (11:19-20). Neither Rahab and her clan, nor the Gibeonites, were Israelite, yet they (and perhaps others) were now part of Israel. Israel's identity is not ethnic, but finds ways to include the foreigner, with Rahab indeed as the paradigm figure for these chapters.

\section{THE LAND ALLOCATION IN JOSHUA 13 - 21}

When we move into chapters $13-21$, it is immediately clear that we are encountering a very different type of literature. However, there are clear elements which show that these chapters are meant to be read in light of chapters 1-12. For instance, we might note the function of the charge to Joshua in 13:1 which has clear parallels to Yahweh's earlier speech in $1: 1-2$. In spite of the lists of cities and kings captured in chapters 10-12, it is clear that Joshua 1-12 has in fact only described certain regions as having been defeated, something that is consistent with the claim here that much of the land remained to be taken. Moreover, just as chapters 1-2 function as a double introduction to the taking of the land, so these chapters are a double introduction to the land allocation. Joshua 1 provides an introductory speech from Yahweh before focusing on the place of all Israel and especially the cis-Jordanian tribes while Joshua 2 establishes the 
importance of a paradigm foreigner. Here, Joshua 13 has the introductory speech from Yahweh (13:1-7), while the rest of the chapter focuses on the completion of the cis-Jordanian allocation ${ }^{4}$ before introducing Caleb as a paradigmatic foreigner in Joshua 14.

Caleb's importance for Joshua 14 cannot be missed, because he demonstrates the sort of faith in Yahweh that is expected of Israel as they claim the land. When he approached Joshua, he did so on the basis of wholehearted faithfulness (v. 8, ואנכי מלאתי אחרי יהוה אלהי in the initial spying out of the land (a further parallel with Joshua 2) as recounted in Numbers 13-14. Further, his recounting of Moses' earlier promise of land functions as a declaration of faith that is closely parallel to that of Rahab, though of course it comes from a position of already being a member of Israel since Caleb presents his request for land as one of the people of Judah.

However, there is one particularly distinctive element in Caleb's presentation in Joshua, and that is that he is particularly referred to as "the Kenizzite" (Josh. 14:6, 14) in this chapter. Although Caleb is a significant figure elsewhere, being mentioned ten times in Numbers and Deuteronomy, the only other time he is called "the Kenizzite" is in Numbers 32:12, where he is listed with Joshua as one of the two faithful spies, using language very similar to Caleb's own declaration (כי מלאו אחרי יהוה).

Given that this is such an unusual way of designating Caleb (son of Jephunneh is normal) we might wonder why this term is given such prominence at this point of the book. The answer, in light of the parallels with chapters 1-2, is perhaps unsurprising. This is an important way of noting that Caleb is a foreigner and not a native Israelite.

The term Kenizzite first occurs in Genesis 15:19, where it specifies one of the peoples whom the descendants of Abraham are to displace, seemingly referring to a people resident in the south of Canaan. In Genesis $36: 11,15$ and 42, Kenaz appears as a descendant of Esau, and this appears to be the particular association intended for Caleb. Evidence for this is also seen in the fact that Othniel, who is a kinsman of Caleb, is described as a "son of Kenaz" in Joshua 15:19. Although 1 Chronicles 4:13, 15 integrates Caleb into the tribe of Judah, it does not do so in a way which removes the fact that he is still a foreigner. Joshua, therefore, accentuates an otherwise relatively minor point about Caleb, which is that his roots are foreign, while also holding him up as the paradigm figure for these chapters, the one who establishes the model for the rest of Israel for what it means to claim the land Yahweh is giving.

$4 \quad$ Levi is also important here $(13: 14,33)$, though this is because of the importance they will play in closing off this section in chapters 20-21 (Firth, 2015: 148). 
As a paradigm figure, it is therefore perhaps unsurprising that the next significant figures in these chapters are also foreigners, since both Achsah and Othniel (Josh. 15:16-19) are members of Caleb's family. They, too, are confident of claiming the land, and so stand in contrast to the position of the Joseph tribes who claim that they have too little land and admit their uncertainty about claiming the forested country in the hills because of the power of the Canaanites there and their iron chariots (Josh 17:14-18). Along with these important individuals, these chapters also acknowledge the continued existence of groups like the Geshurites and Maacathites (13:13) and Jebusites (15: 63). But where their continued presence in Israel could be taken as a sign of failure on Israel's part, there is a more ambiguous relationship with both the Archites and Japhletites within the allotment for Ephraim (16:2-3), since the description of Ephraim's territory seems to assume that they will continue to exist within Israel. It is notable too that, apart from the Japhletites who are never mentioned again, each of these groups is prominent (though rather ambiguously) in the time of David (e.g. 2 Sam. 3:3, 10:6, 13:37-38, 23:4), especially the Archites since Hushai the Archite can be designated as David's "friend" (2 Sam 15:37, 16:16), a term which here refers to an important counsellor within the royal court.

As with the account of the taking of the land, so also the land allocation chapters presume that other foreigners are included within Israel, so that the cities of refuge are also designated for the גר as well as the people of Israel (Josh. 20:9). Caleb is the paradigm figure because, like Rahab, he lives out faith in Yahweh, but this in turn leaves open the possibility that other foreigners might join Israel. What matters is faith, demonstrated through commitment, to Yahweh. The identity of Israel assumed by the book of Joshua is thus not defined by ethnicity. Instead, it is a faith community, one in which an Israelite like Achan can be excluded, but which is open to others who embrace faith in Yahweh as something lived out.

\section{THE PLACE OF ABRAHAM AND PEOPLE IN JOSHUA 24}

This background within the book thus prepares for the mention of Abraham in Joshua's speech and its references to other gods, references which within the book are also related to the presence of foreigners. In fact, in this speech Joshua does not begin with Abraham when discussing Israel's ancestors, but rather with Terah who was Abraham's father and Nahor (Josh. 24:2, c.f. Gen. 11:27). When they lived beyond the Euphrates, it was Terah who served other gods, so that when Yahweh took Abraham 
and brought him to the land of Canaan it is clear that he took Abraham from a family that served other gods. Genesis never claims that Abraham served only Yahweh, but it does make clear that he served Yahweh above all others. Nevertheless, he was someone who became Israel's ancestor because of Yahweh's initiative. As Joshua tells the story, therefore, although the subsequent presentation will assume that Abraham's devotion was to Yahweh, there is a deliberate focus on the incongruity of Abraham as the nation's founding ancestor. But within a book that has consistently shown ways in which people can make commitment to Yahweh their defining mark, it is then possible for a change of status to occur. As a result, the tension which Rösel (2011:365), among others, finds between the presentation of Abraham in verse 2 (which emphasises his original status as an idolater) and the subsequent presentation (which does not) misses the point. The book has consistently shown that those who had served other gods can become worshippers of Yahweh and so be integrated into the life of Yahweh's people provided their subsequent life is consistent with this. Since Genesis has never cast doubt on Abraham's fidelity to Yahweh, and indeed this was tested in Genesis 22:1-19, then it becomes clear that Abraham fits the pattern we have seen in the earlier parts of the book. ${ }^{5}$ Rahab, the foreigner, was the paradigm figure for chapters 1-12, Caleb, also of foreign extraction, was the paradigm figure for chapters 1321. Here, Joshua reaches back to Abraham to provide the paradigm figure, but once again the paradigm figure is one whose origins were foreign and rooted in the worship of other gods. As Butler $(2014: 2,316)$ puts it:

The text underlines the shocking truth that Yahweh worship did not begin at creation for a people called Israel but only at the dawn of the people Israel with one family who did not inhabit the land Israel, or worship Yahweh, the God of Israel.

Further reinforcing this point is Hawk's observation (2000:269) that the phrase "across the river" (בעבר הנהר) always carries the sense of outsider status, since it has referred either to kings and peoples of the land $(2: 10,5: 1,9: 1,10,12: 1)$ or the cis-Jordanian tribes and their territory (1:14, $15,13: 8,27,32,14: 3,17: 5,20: 8)$. These are not the people who can claim automatic entry into Israel because of their outsider status, and yet a consistent emphasis of the book is that the cis-Jordanians do indeed belong with Israel even though they live outside the land. Moreover, although describing someone as being from "across the river" marks them out as foreigners who are not part of Israel, it is also notable that each of

5 Interestingly, in Genesis 35:1-4, Jacob is required to put aside other gods, but this is not a theme picked up here because of the paradigmatic function given to Abraham. 
the references to these kings occurs in a context which describes how some foreigners came to be included within Israel. So, the phrase actually functions at two levels - it is a marker of those who do not automatically belong within Israel, and yet also points to the possibilities that exist for these peoples to become part of Israel.

A further and remarkable aspect of Joshua's speech here is the way time is collapsed, so that the clear historical difference between those who were actually involved in the exodus and the entry into the land is removed. Thus, in verse 6 , Joshua speaks of bringing the people's ancestors out of Egypt, so that the exodus generation is treated as being separate from the one present at Shechem. Yet, in verse 5 he speaks of having brought "you" out, which is the people before him. Similarly, in verse 7, although those present at the exodus were the ones said to have cried out to Yahweh for deliverance at the Sea of Reeds, Joshua positions those being addressed in the crossing of the Sea. Indeed, from this point on, Joshua rhetorically places his audience at each of the points narrated, even though within the book's own narrative it is clear that they were not present at any of these events. There is no doubt that the book is aware of the historical difference between these generations, but this collapsing of time, which is typical of liturgical texts, is an intentional feature of the speech. It becomes a mechanism by which even those within Israel who could not claim any ethnic association with Israel can now claim to be part of the story of salvation that Joshua narrates because they too are now worshippers of Yahweh. The collapsing of time and place, which is a feature of this speech, functions rhetorically to enable those who were not originally part of Yahweh's saving purpose to join that purpose, even as Abraham, Caleb and Rahab had, and claim these saving acts as their own. Moreover, it is striking that in chapter 24 there is no longer any mention of other nations, only other gods (Mitchell, 1993:117). The shape of Israel that has been emerging through the book is one that is defined by faith, not by nationality, but that faith community will in turn become a nation. Moreover, this nation has come to occupy its present land by Yahweh's initiative and not Israel's power, a point that is stressed by the otherwise obscure reference to the hornet as the means by which the land was given rather than through sword and bow (Josh. 24:12-13). But crucially for our purposes, the people who have received this are a people made up of diverse origins and geography. It is this Israel, mixed in so many ways, who are said to have served Yahweh all the days of Joshua (24:28). 


\section{ETHICAL TRAJECTORIES FROM JOSHUA}

Following Wenham's (2000) model of ethical reading of Old Testament narrative, we have so far sought to identify those features which are commended by the narrator of the text. What has emerged is that the book of Joshua establishes a pattern which prominently displays the included foreigner, vindicating even those decisions which might otherwise have been disputed, such as the oath to Rahab and the covenant with Gibeon, and otherwise encouraging a positive attitude towards those foreigners who recognise Yahweh. That is, the book is commending this as an appropriate attitude within Israel. The ways in which it does so, in particular its introduction of Rahab without a direct explanation of the appropriateness or otherwise of the oath sworn to her by the scouts, suggests that the book is resistant to a then dominant approach which was prepared to reject all foreigners while constructing an alternative understanding of Israel's identity. This reading of the text stands against those which have emphasised the destruction of foreigners in the book as a means of countering internal resistance within Israel (e.g. Rowlett, 1996) because it recognises that more space within the book is given to ways in which unexpected groups are included within Israel in the book, and that Joshua 24 is thus a deliberate capstone to this process. The book of Joshua thus seeks to undermine a view of foreigners (and, one might add, those who dwell outside the promised boundaries of the land) which rejected them precisely because they were not Israelite. Within Joshua, Israel is continually being reformed, redefined as a community which includes all who share its faith in Yahweh. Foreigners, even those who would most obviously appear to be candidates for destruction, are included. The dominant social position within Israel when the book was composed would appear to be one which was negative towards foreigners, which is why the book needs to introduce its topic so carefully.

Beyond Joshua, this attitude is then picked up in the remaining of the books of the Former Prophets, each of which in turn emphasises the faith of foreigners who can then become part of Israel, or in the case of Naaman at least someone who is a part of the faith community even though he does not dwell within Israel. We can only sketch these briefly.

For the book of Judges, Othniel - a kinsman of Caleb and thus of foreign stock - is presented as the paradigm judge, the only major judge not to demonstrate some significant failing (Jdg. 3:7-11), while in the story of Deborah it is Jael, a Kenite and so not an Israelite, who gains glory in the defeat of Sisera (Jdg. 4). In passing, we can also note that the first of the minor judges, Shamgar, is most probably a foreigner since his name is not Israelite (see Lindars, 1995: 157-158). Shamgar thus becomes part 
of a pattern that runs through the book of Judges where the deliverer figures are quite unexpected, but his particular feature is that he is foreign (c.f. Chisholm, 2013:200-201).

The books of Samuel likewise highlight the place of foreigners, putting them in paradigmatic positions while also making direct connections with the book of Joshua. Two examples will suffice. First, David's "friend" Hushai is repeatedly referred to as "the Archite" (2 Sam 15:32, 16:16, 17:5, 14). The term indicates that he is a member of the surviving Canaanite population hinted at in Joshua 16:2. Hushai displays loyalty to David which exceeds that of many, taking on the risky role of being David's agent in Jerusalem while Absalom ruled, and is specifically said to be the one through whom Yahweh worked in thwarting Ahithophel's good advice (2 Sam 17:14). A second Canaanite is Araunah the Jebusite, a member of a community whose survival was noted in Joshua 15:63 and who apparently endured beyond David's capture of the city (2 Sam 5:610). Following the sin of David's census, and following Gad's directive, David purchased Araunah's threshing floor to build an altar to Yahweh (2 Sam 24:15-25). The portrayal of Araunah throughout is of someone who is sensitive to what Yahweh is doing and who is prepared to work with David, and indeed to give David what he needs, even though David insists on making full payment. However, the important point from our perspective is that the books of Samuel insist that there were Canaanites who continued to live among Israel and who made a positive contribution to the life of Israel because of faith in Yahweh. Beyond these, we can also note examples such as Ittai the Gittite, a Philistine mercenary who expresses faith in Yahweh as the reason for his continued loyalty to David (2 Sam 15:21). We have all this without even mentioning Uriah the Hittite. It is also notable that the positive portrayal of foreigners is a distinctive element of David's court as opposed to Saul's, and, given the obvious preference of these books for David over Saul, this too is an indicator of their positive attitude towards foreigners who embrace faith in Yahweh, or at least do not seek to oppose it.

This positive attitude to foreigners is taken further in the books of Kings. Again, we can take only a few examples, but this attitude is particularly clear in Solomon's prayer of dedication for the temple which makes special note of the foreigner who comes to the temple to pray because they have heard of Yahweh in a distant land as one who should be accepted by Yahweh (1 Kgs. 8:41-43). Strikingly, this is the נכר (a word that does not occur in Kings) so that the foreign status of this person is particularly emphasised. Of course, this probably presumes that this foreigner will not take up residence in Israel, but what matters is that these foreigners have heard of Yahweh's fame, not that of Solomon (Wray Beal, 2014: 139). Solomon's prayer then anticipates the record of how Yahweh will work 
among foreigners who therefore remain as foreigners rather than having to be integrated into Israel through the book. So, Elijah will be sent to the widow of Zarephath, a town which is specifically said to belong to Sidon, where he will provide both a feeding miracle and a resuscitation of the woman's dead son (1 Kgs 17:8-24). ${ }^{6}$ Yahweh is able to work among foreigners who remain as foreigners, and this in turn prepares us for the healing of Naaman, an Aramean who is able to become a worshipper of Yahweh in spite of the pressures placed on him because of his prominence in the Aramean court. Gehazi then serves as a contrast to Naaman in much the same way as Achan does to Rahab - now the Israelite receives the affliction of the foreigner because he seeks to claim wealth that is not rightly his. So, where the earlier books of the Former Prophets had shown the possibility of foreigners being accepted and incorporated into Israel because of their faith in Yahweh, Kings now allows for the possibility of a positive view of foreigners, including those who might otherwise have generated fear because of their military prowess, for exactly the same reason.

The emerging paradigm of these books is one which gradually breaks down barriers built on the basis of ethnicity and instead focuses on the possibility of shared faith and values as that which builds community. Those shared values might not be deeply held - the Gibeonites illustrate this - but they are the means by which an alternative community might be built, a community which transcends the borders of the ancient world. This paradigm is not one which is trumpeted directly, perhaps because to do so would mean that those with entrenched power and who rejected foreigners would see too easily the critique of their position. Instead, this is a critique which emerges from a position of social weakness while offering a different and more inclusive view of the foreigner, whether they are a migrant or someone who remains outside of Israel. It is this pattern which continues into the New Testament too, but that would go beyond the boundaries of this paper.

6 By contrast, the closely similar miracles involving Elisha (2 Kgs 4:1 - 37) are directed at Israelites. 


\section{BIBLIOGRAPHY}

BILLINGS, R.

2013. "Israel Served the Lord":The Book of Joshua as a paradoxical portrait of faithful Israel. Notre Dame: University of Notre Dame Press.

ButLeR, T.C.

2014. Joshua. WBC, 2 vols, $2^{\text {nd }}$. ed., Grand Rapids:Zondervan.

ChISHOLM, R.B.

2013. A commentary on Judges and Ruth. Grand Rapids:Kregel Academic.

COOTE, R.B.

1998. Joshua. In: L.E. Keck (ed.), The New Interpreter's Bible, vol. 2, (Nashville: Abingdon), pp. 555-719.

CoWles, C.S.

2003. The case for radical discontinuity. In: S.N. Gundry (ed.), Show them no mercy: Four views on God and Canaanite genocide, (Grand Rapids: Zondervan), pp. 11-46.

DAWKINS, $R$.

2006. The God Delusion. London:Black Swan.

EARL, D.S.

2010. Reading Joshua as Christian Scripture. Winona Lake:Eisenbrauns

FIRTH, D. G.

2009. 1 \& 2 Samuel. AOTC, Nottingham:Apollos.

2015. The Message of Joshua: Promise and People. BST, Nottingham:IVP.

2017a. Models of inclusion and exclusion in Joshua. In: H. Hagellia \& M. Zehnder (eds.), Interreligious relations, (London: T \& T Clark), pp. 70-88.

2017b. Disorienting Rraders in Joshua 1:1-5:12, JSOT 41:413-430.

FORD, W.

2015. What about the Gibeonites? TynBull 66:197-216.

Genette, G.

1980. Narrative discourse: An essay in method. Ithaca: Cornell University Press.

García-Alfonso, C.

2010. Resolviendo: Narratives of survival in the Hebrew Bible and in Cuba today. New York: Peter Lang.

HAwK, L.D.

1991 Every promise fulfilled:Contesting plots in the Book of Joshua. Louisville: Westminster John Knox.

2000. Joshua. Collegeville: Liturgical Press. 
KOOREVAAR, H.J. 1990. De Opbouw van het Boek Jozua. Heverlee:Centrum voor bijbelse Vorming België.

KRAUSE, J.J. 2014. Exodus und Eisodus: Komposition und Theologie von Josua 1-5. Leiden:Brill. https://doi.org/10.1163/9789004267794

2015. Aesthetics of production and aesthetics of reception in analyzing intertextuality: Illustrated with Joshua 2, Biblica 96.

LINDARS, B.

1995. Judges 1-5:A new translation and commentary. Edinburgh:T \& T Clark.

ManN, T.W.

2011. The Book of the Former Prophets. Eugene: Cascade.

MitChelL, G.

1993. Together in the land:A reading of the book of Joshua. Sheffield:JSOT Press.

Rösel, H.N.

2011. Joshua. HCOT, Leuven:Peeters.

ROWLETT, L.L. 1996. Joshua and the rhetoric of violence: $A$ new historicist analysis. Sheffield:JSOT Press.

SPERLING, S.D.

1987. Joshua 24 re-examined. HUCA 58:119-136.

Wenham, G.J. 2000. Story as Torah: Reading Old Testament narrative ethically. Grand Rapids:Baker Academic.

Winther-NieLsen, $\mathrm{N}$. 1995. A functional discourse grammar of Joshua: A computer-assisted rhetorical structure analysis. Stockholm:Almqvist \& Wicksell

WRAY BEAL, L.M.

2014. 1 \& 2 Kings. AOTC, Nottingham:Apollos.

ZEHNDER, M.

2005. Umgang mit Fremden in Israel und Assyrien: ein Beitrag zur Anthropologie des »Fremden« im Licht antiker Quellen. Stuttgart:Kohlhammer.

2013. The annihilation of the Canaanites: Reassessing the brutality of the Biblical witnesses. In: M. Zehnder \& H. Hagelia (eds), Encountering violence in the Bible, (Sheffield: Sheffield Phoenix), pp. 263-290. 
KEYWORDS

Joshua

Foreigners

Narrative criticism

Identity
TREFWOORDE

Josua

Vreemdelinge

Narratiewe kritiek

Identiteit 